\title{
Ultrastructural glomerular changes in experimental infection with the classical swine fever virus
}

\author{
Norma L. CALdERÓN ${ }^{\mathrm{a} *}$, Leopoldo H. PAASCH ${ }^{\mathrm{a}}$, Teresa I. ForTOUL ${ }^{\mathrm{b}}$ \\ a Facultad de medicina veterinaria y zootecnia, UNAM, \\ Departamento de producción animal: aves, Ciudad Universitaria, 04510 México D.F., México \\ ${ }^{b}$ Facultad de medicina, UNAM, Departamento de biología celular y tisular, \\ Ciudad Universitaria, 04510 México D.F., México
}

(Received 26 January 1999; accepted 30 March 2000)

\begin{abstract}
Ultrastructural studies of glomerular changes were performed on 16 pigs experimentally infected with a highly virulent strain of the classical swine fever virus. Our observations revealed the thickening of glomerular basement membranes, swelling of endothelial cells and cytoplasmic vacuolization within podocytes containing abundant viral particles. An early viral infection of podocytes was suggested as the cause of selective swelling of the foot processes of these cells with the consequent obliteration of the glomerular urinary spaces. To our knowledge this is the first report of ultrastructural evidence of classical swine fever virions infecting glomerular podocytes.
\end{abstract}

classical swine fever / glomerulus / ultrastructure / pathology

Résumé - Évolution de l'ultrastructure des glomérules rénaux lors d'une infection expérimentale par le virus de la peste porcine classique. Une étude en microscopie électronique des glomérules rénaux a été réalisée afin de mieux appréhender l'évolution de leur ultrastructure lors de l'atteinte rénale associée à la peste porcine classique. Les prélèvements ont été réalisés sur 16 porcelets infectés expérimentalement par une souche très virulente du virus de la fièvre porcine classique. Nos observations ont montré un épaississement de la membrane basale, une tuméfaction des cellules endothéliales associée à la présence de vacuoles dans le cytoplasme des podocytes. De nombreuses particules virales ont été observées dans le cytoplasme des podocytes. Une infection virale précoce des podocytes semble probable, et pourrait expliquer la tuméfaction spécifique de la protubérance podale de ces cellules, et par voie de conséquence, l'obstruction de l'espace urinaire glomérulaire. Actuellement, cette étude est la première à mettre en évidence par ultrastructure des particules virales de la peste porcine classique dans les podocytes glomérulaires.

fièvre porcine classique / glomérule rénal / pathologie / ultrastructure

* Correspondence and reprints: Av. Ejido 159, Vergel del Sur, 14340 México D.F., México.

Tel.: (525) 61669 23; fax: (525) 62258 68; e-mail: nlca@ servidor.unam.mx 


\section{INTRODUCTION}

Acute glomerulonephritis is a common lesion in systemic viral diseases. Acute infectious canine hepatitis, equine viral arteritis, Newcastle Disease, and acute Classical Swine Fever (CSF) are examples of diseases in which viruses replicate in the cells of the glomerulus [4].

Immunohistochemical studies have been useful in localizing infected glomerular cells. A major structural protein of the envelope of the CSF virus is glycoprotein 55 which can be detected using a monoclonal antibodybased immunohistochemical test. In CSF experimental infections, immunoreactive products were detected using the aforementioned test in the glomeruli including in the group of positive cells, circulating monocytes and endothelial cells [6].

Former experimental work has mentioned the difficulty in locating virions in infected glomerular cells with several viral diseases, including CSF. The adenovirus infection is an exception since the virions are located in the nuclei of endothelial and mesangial cells [17]. More recent ultrastructural evidence of the CSF virus cell infection indicates the presence of viral particles in degenerated megakaryocytes, suggesting that megakaryocyte damage caused by this virus might be responsible for the thrombocytopenia detected in early stages of the disease $[1,8]$. In chronic cases of CSF, the presence of $53 \mathrm{~nm}$ virus-like particles has been observed by transmission electron microscopy in the epithelial cells of tonsils; however, detailed viral morphology of the CSF virus has not been described [3].

Many authors have reported glomerular lesions in CSF [2, 3, 16] and the majority of them described the hyperactive swelling of the glomerular cells as the most important finding. The aforementioned change has been interpreted as an expression of increased phagocytic activity and protein synthesis [16]. The phagocytic activity of podocytes and mesangial cells has been doc- umented in cases where the filtering capacity of the basement membrane has been impaired [4]. Since basement membrane splitting is commonly found in CSF, the observation of dense bodies within podocytes and mesangial cells is suggested as an evidence of phagolysosomes containing material derived from disrupted basement membranes [16].

Podocytes and mesangial cells are also known to participate in basement membrane and mesangial matrix repair [12]. Therefore, basement membrane damage in CSF explains the activation of ribosomes and polysomes of glomerular, epithelial and mesangial cells due to increased protein synthesis necessary for the repair of damaged membranes [16].

The aim of the present study was to obtain ultrastructural evidence of reactive changes in glomerular cells such as those described above, and also to evaluate possible glomerular cell infection caused by the CSF virus in experimental cases.

\section{MATERIALS AND METHODS}

Sixteen crossbred, six to eight week old pigs obtained from farms free of CSF and corroborated as negative to antibodies against the CSF virus by the serum neutralization test, were infected by a single intramuscular $10^{6}$ tissue culture infecting dose $50 \%\left(\mathrm{TCID}_{50}\right)$, the Ames Iowa highly virulent strain of the CSF virus [2]. Four pigs used as controls were inoculated with a single intramuscular dose $1 \mathrm{~mL}$ of phosphate buffered saline (PBS), pH 7.2 and euthanized on the eighth day. The procedures with experimental and control pigs were conducted according to the regulations established for animal welfare at the Faculty of Veterinary Medicine of the National Autonomous University of Mexico.

For ultrastructural studies, two infected pigs were euthanized daily for eight consecutive days beginning at day 1 post infec- 
tion, by an anaesthetic overdose (Aneste$\mathrm{sal}^{\circledR}$ SmithKline Beecham, Mexico). Immediately, samples of cortical parenchyma from the kidneys were taken for histological and electron microscopy studies. Tissue samples were fixed in $2.5 \%$ glutaraldehyde $0.1 \mathrm{M}$ sodium cacodylate buffer, $\mathrm{pH} 7.4$ $\left(470 \mathrm{mosmol} \cdot \mathrm{L}^{-1}\right)$ and cut into 3 to $5 \mathrm{~mm}$ pieces, postfixed in $1 \%$ osmium tetroxide for two hours, dehydrated in an alcohol series and embedded in Epon 812. Semithin $90 \mathrm{~nm}$ thick sections were stained with $1 \%$ aqueous toluidine blue solution, and observed with a light microscope to select suitable blocks. Thin $60 \mathrm{~nm}$ thick sections were contrasted with uranyl acetate and Reynold lead citrate. Sections were observed and photographed with a Zeiss EM 109 transmission electron microscope.

\section{RESULTS}

All infected pigs became febrile on day 1 post infection. Other clinical signs observed were characteristic of acute classical swine fever, and appeared progressively after the onset of fever. They included anorexia, apathy, diarrhea, vomiting, incoordination and skin erythema. Control pigs remained asymptomatic during the experiment. No macroscopic lesions were detected in infected or in control pigs.

No light microscopy findings for infected pigs were observed on days 1 to 3 post infection, the changes for infected pigs appeared at day 4 post infection and were also detected in animals euthanized the following days. They revealed a segmental thickening of the glomerular basement membrane and a nuclear swelling of endothelial cells. Several areas of the urinary space contained eosinophilic homogeneous material. Some renal tubules were affected with vacuolization of epithelial cells and eosinophilic homogeneous material was also found in the tubular lumen. No lesions were detected in control pigs in light microscopy observations.
Ultrastructural observations on days 1 to 3 post infection revealed thickening of the glomerular basement membranes especially in areas where the contiguous mesangium exhibited cell proliferation. Shortening and fusion of podocyte foot processes were prominent. Examination of the mesangial cells revealed severe cytoplasmic vacuolization (Fig. 1).

At day 4 to 6 postinfection, glomerular basement membranes were fragmented and the nuclei of endothelial cells were conspicuously swollen. Severe swelling of foot processes of podocytes was observed. Numerous electron dense particles were found within dilated vesicular structures of podocytes (Fig. 2). These electron dense particles, from 40 to $60 \mathrm{~nm}$ in diameter, had a spherical shape and presented an electron dense core covered by a less electron dense outer coat. Similar particles were also observed along the cytoplasmic membranes of the terminal foot processes. Proliferation of mesangial cells continued to be present at this stage in focal areas of all glomeruli observed.

At days 7 to 8 post infection, the glomerular filtration membrane was very poorly defined and podocytes containing large vesicles filled with cell detritus were evident.

No ultrastructural changes were detected in kidney sections of control pigs.

\section{DISCUSSION}

The clinical signs that appeared in infected pigs in the present study were consistent with those described in the literature for acute CSF [5, 7, 15].

Thickening and fragmentation of basement membranes, previously reported in the glomeruli of pigs affected with CSF [16], were also common findings in the present study. Mesangial cell proliferation found in our study might be interpreted as a mechanism for compensatory secretion of 


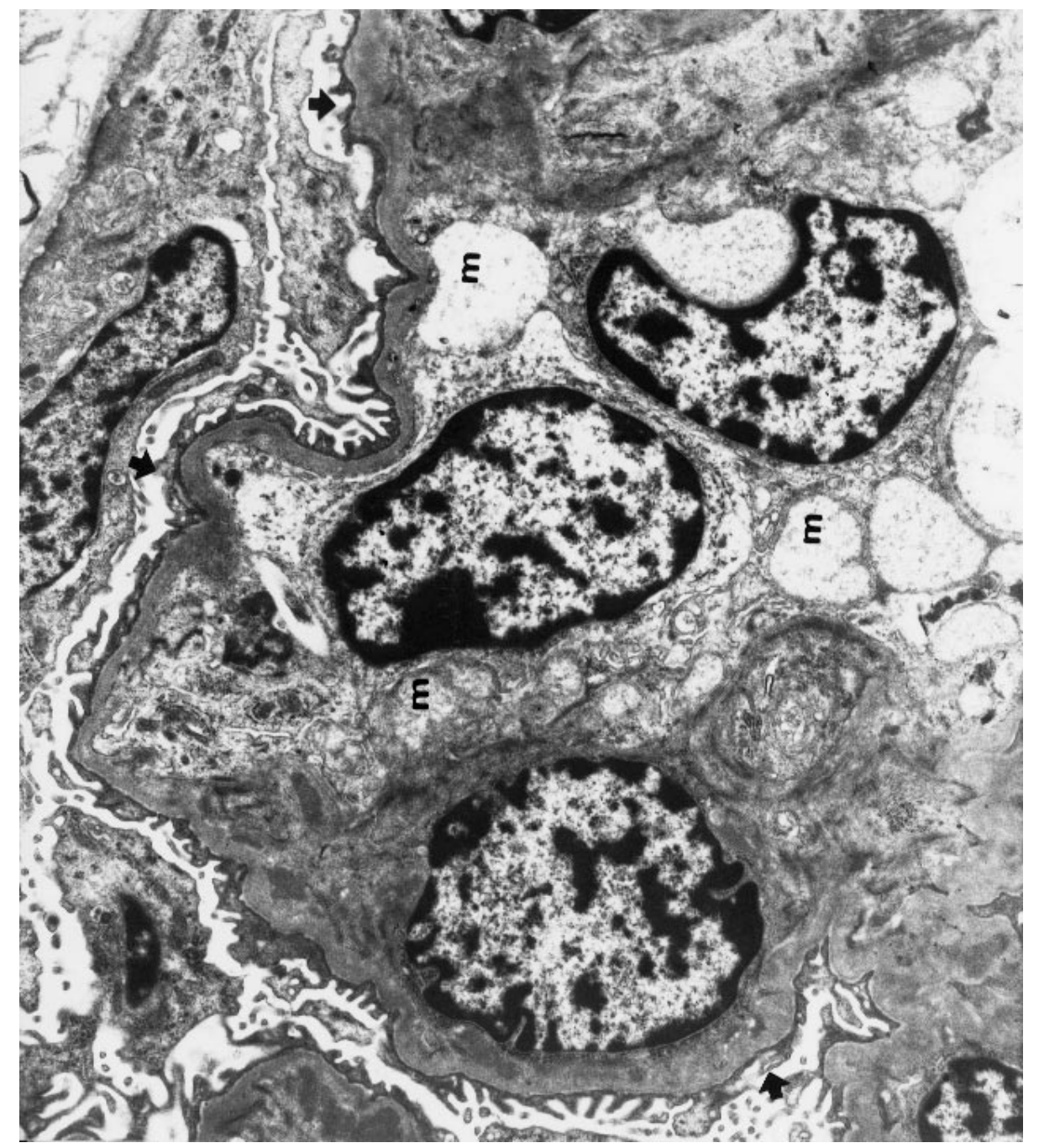



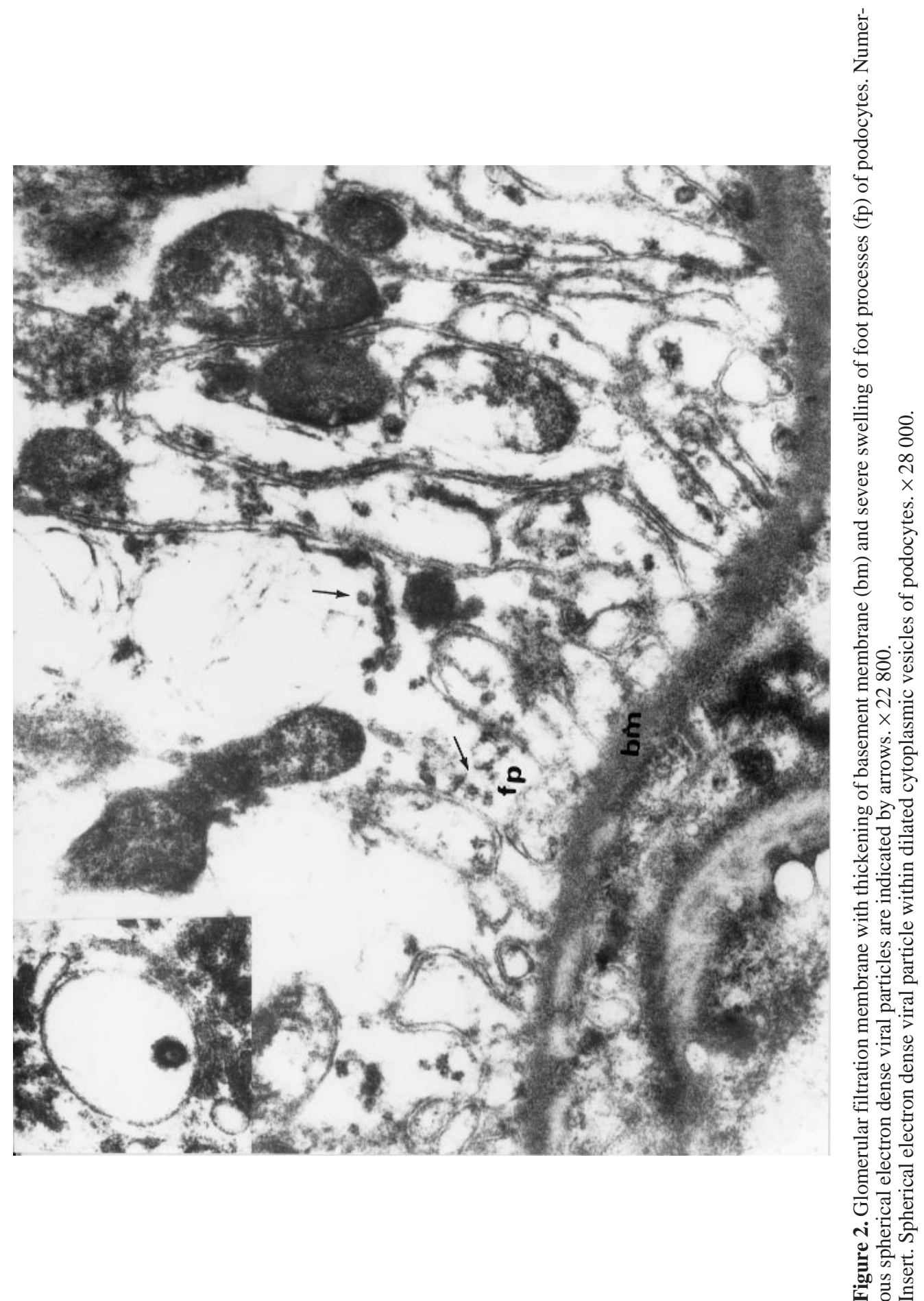
basement membrane material and also as a reactive change derived from swelling and lysis of the same affected cells [11].

Previously conducted immunohistochemical studies suggest that infected glomerular cells are mainly circulating monocytes and endothelial cells [6]. Endothelial cell infection with the CSF virus has been demonstrated by several authors [3] and may explain basement membrane damage. However, we were not able to document viral infection of endothelial cells although these cells were remarkably swollen.

Dense bodies within podocytes described previously in the literature [16], have been interpreted as phagolysosomes containing material derived from fragments of the disrupted basement membrane. However, in our study, podocytes were affected with conspicuous swelling in which vesicles contained numerous electron dense spheres corresponding to viral particles. Previous studies undertaken specifically to document the CSF viral particles under transmission electron microscopy, reveal the viruses as spherical structures with an electron dense core and a less electron dense outer coat, with an average diameter of $50 \mathrm{~nm}[2,9,13,14]$.

Ultrastructural evidence of cell infection by the CSF virus affecting the epithelial cells of tonsils was suggested in earlier work [2]. More recent observations of the CSF virus in experimental infection mention viral particles which were present from as early as the first day post infection in cytoplasmic vesicles of megakaryocytes [1].

Particles observed in our study in the podocytes had the same morphology and size characteristics as those previously described.

Our findings suggest that early viral infection of podocytes in acute CSF might produce selective swelling of the foot processes of these cells. It is known that any process causing cell swelling of podocytes tends to obliterate the urinary spaces by compressing the foot processes against the basement membrane [10].

\section{ACKNOWLEDGEMENTS}

We thank MVZ. P. Bizarro, Dr. S. Antuna and Dr. A. Rondan for their electron microscopy technical assistance, and Mr. F. Pasos for his invaluable support with the illustrations.

\section{REFERENCES}

[1] Calderón N.L., Fortoul T.I., Paasch L.H., Bouda J., Pathogenesis of thrombocytopenia in acute classical swine fever, Acta Vet. Brno 67 (1998) 115-119.

[2] Cheville N.F., Mengeling W.L., The pathogenesis of chronic hog cholera (Swine Fever), Lab. Invest. 20 (1969) 261-274.

[3] Cheville N.F., Mengeling W.L., Zinober M.R., Ultrastructural and immunofluorescent studies of glomerulonephritis in chronic hog cholera, Lab. Invest. 22 (1970) 458-467.

[4] Cheville N.F., Kumar V., Robbins S.L., Cell Pathology, 2nd. ed. The Iowa State University Press Ames Iowa, USA, 1983.

[5] Dahle J., Liess B., A review on classical swine fever infections in pigs: Epizootiology, clinical disease and pathology, Comp. Immunol. Microbiol. Infect. Dis. 15 (1992) 203-211.

[6] de las Mulas J., Ruíz-Villamor E., Donoso S., Quezada M., Lecocq C., Sierra M.A., Immunohistochemical detection of hog cholera viral glycoprotein 55 in paraffin-embedded tissues, J. Vet. Diagn. Invest. 9 (1997) 10-16.

[7] Dunne H.W., Hog cholera (European swine fever), Adv. Vet. Med. 17 (1973) 315-359.

[8] Gómez-Villamandos J.C., Ruíz-Villamor E., Salguero F.J., Bautista M.J., Carrasco L., Sánchez C., Quezada M., Sierra M.A., Immunohistochemical and ultrastructural evidence of hog chlolera virus infection of megakaryocytes in bone marrow and spleen, J. Comp. Pathol. 119 (1998) 111-119.

[9] Horzinek M., Reckzko E., Petzoldt K., On the morphology of hog cholera virus, Arch. Gesamte Virusforsch. 21 (1967) 475-478.

[10] Kerjaschki D., Polycation-induced dislocation of slit diaphragms and formation of cell junctions in rat kidney glomeruli, Lab. Invest. 39 (1978) 430-440.

[11] Morita T., Kihara I., Oite T., Yamamoto T. Suzuki Y., Mesangiolysis, Lab. Invest. 38 (1978) 94-102.

[12] Rhodin J.A.G., Histology, A text and atlas, 2nd printing, Medical College, New York, 1977. 
[13] Ritchie A.E., Fernelius A.L., Direct immunoelectron microscopy and some morphological features of hog cholera virus, Arch. Gesamte Virusforsch. 23 (1968) 292-298.

[14] Scherrer R., Aynaud J.-M., Cohen J., Bic E., Étude au microscope électronique du virus de la peste porcine classique (hog cholera) dans des coupes ultra-fines des cellules infectées in vitro, C.R. Hebd. Seances Acad. Sci. D 271 (1970) 620623.
[15] Terpstra C., Hog cholera: An update of present knowledge, Br. Vet. J. 147 (1991) 397-406.

[16] Thiel W., Weiss E., Elektronenmikroskopische Veränderungen der Glomerula und NierengefäBe bei akuter Schweinepest, Berl. Münch. Tierärztl. Wochenschr. 89 (1976) 71-74.

[17] Wright N.G., Thompson H., Cornwell H.J.C., Morrison W.I., Ultrastructure of the kidney and urinary excretion of renal antigens in experimental canine adenovirus infection, Res. Vet. Sci. 14 (1973) 376-380 